\title{
Assisted Revegetation Following Contaminated Site Remediation in the Arctic: Four-Year Case Study of a Former Radar Site
}

\author{
Sarah Ficko',2, Brandon Smith', Barbara Zeeb ${ }^{1 *}$ \\ ${ }^{1}$ Department of Chemistry and Chemical Engineering, Royal Military College of Canada, Kingston, Canada \\ ${ }^{2}$ Present Address: 821 General Services Building, Department of Renewable Resources, University of Alberta, \\ Edmonton, Canada \\ Email: ${ }^{*}$ zeeb-b@rmc.ca
}

Received 31 March 2015; accepted 25 May 2015; published 28 May 2015

Copyright (C) 2015 by authors and Scientific Research Publishing Inc.

This work is licensed under the Creative Commons Attribution International License (CC BY). http://creativecommons.org/licenses/by/4.0/

(c) (7) Open Access

\section{Abstract}

Cape Dyer (DYE-M), located on the easternmost point of Baffin Island, is a former DEW line radar station built in 1956-57 which was upgraded in 1993 as part of the current North Warning System. Environmental studies in the late 1990s and early 2000 s determined that extensive soil contamination existed across the site, and excavation of six landfills and subsequent reshaping of the area in 2008 disturbed approximately $19,700 \mathrm{~m}^{2}$. A four-year pilot project was conducted between 2009 and 2012 to investigate feasibility of, and determine methods to, accelerate revegetation of the disturbed area through assisted seed dispersal of native and non native species and selective transplantation of slow-growing shrub species. Prior to revegetation efforts, plant surveys conducted in July 2009 determined that 15 species were present in the undisturbed areas, of which Salix arctica ( 11\%), Vaccinium uliginosum L. ( 8\%), and Empetrum nigrum L. $(\sim 5 \%)$ were the predominant species. A total of 14 species (three new) were observed growing on the disturbed areas between 2010 and 2012. The majority of Lolium multiflorum (annual ryegrass) seeds planted as a nurse species in 2009 grew in 2010, but most were stunted and only observed in furrows or sheltered areas at a low density. Salix arctica Pall. (willow) cuttings planted in "islands" of 20-30 cuttings in fall 2009 had a three-year survival rate of $82 \%$, while a second set of cuttings planted in fall 2011 had a one-year survival rate of $93 \%$. Visual observations indicate that patches of new vegetation are becoming more predominant on the disturbed area, especially around the willow islands, indicating the importance of microtopography for successful reclamation in arctic environments. Monitoring over ten or more years will be required to determine the long term success

"Corresponding author.

How to cite this paper: Ficko, S., Smith, B. and Zeeb, B. (2015) Assisted Revegetation Following Contaminated Site Remediation in the Arctic: Four-Year Case Study of a Former Radar Site. American Journal of Plant Sciences, 6, 1301-1312. 
of this project.

Keywords

Salix arctica, Revegetation, Disturbed Lands, Arctic, DEW Line

\section{Introduction}

Increased human activity and development in northern Canada and other polar environments have accelerated the disturbance of vast tracts of land in an already fragile ecosystem. During the 1950s, 42 Distant Early Warning (DEW) line radar stations were built along the $70^{\circ}$ latitude, and linked with stations in the Polevault line to act as an early detection system for approaching hostile aircraft during the Cold War. Construction, operation and maintenance of these sites resulted in extensive contamination of soils and ground water at numerous locations across the Canadian arctic and subarctic [1] [2]. The Cape Dyer DEW Line station, DYE-M $\left(66^{\circ} 40^{\prime} \mathrm{N}\right.$, $61^{\circ} 21^{\prime} \mathrm{W}$ ) was built in 1956-7 on the easternmost point of Baffin Island, on the Cumberland Peninsula bordering the Davis Strait, to link the DEW Line, Polevaultline, and Greenland communication facilities. The site accommodated several hundred personnel within the upper (radar) and lower (logistical) areas of the site, while equipment brought to site by water was loaded and offloaded at the beach (Figure 1). DYE-M was upgraded to an unmanned radar station as part of the new North Warning System in 1993.

Environmental studies conducted at DYE-M between 1997 and 2001 demonstrated that contaminated soils posed a potential risk to the arctic ecosystem [3] [4]. Remediation work was initiated in 2005 at DYE-M, and completed in 2013. In 2008, extensive remediation work was conducted at the DYE-M beach to remove material from six buried landfills. Subsequent reshaping of the terrain resulted in approximately 19,700 $\mathrm{m}^{2}$ of land completely or partially cleared of vegetation cover, leaving these areas unstable, more vulnerable to wind and water erosion, unable to provide food or habitats for animals, and visually unappealing.

In arctic environments, plant growth is constrained by short growing seasons, harsh environmental conditions (e.g., low temperature and rainfall), low species diversity ( 1000 species) and minimal soil fertility [5]-[7]. Following disturbance or creation of new habitat, plant communities develop and change over time through a series of succession processes [8]. New or severely disturbed sites with no seeds or vegetative propagules develop by primary succession, while sites that lack surface vegetation but have a seedbank or vegetative propagules develop by secondary succession. Reestablishment of plant cover through natural succession events is a significantly longer and slower process in the arctic than in more temperate climates, with estimates of 100 or more years to achieve former plant diversity and coverage [6]-[10]. In previous studies monitoring natural revegetation in the Arctic, the first plants to re-colonize disturbed areas are the most efficient seed (e.g. Drabaspp, Oxyriadigyna, and several grasses) or bulbil producers (e.g. Polygonum viviparum and Saxifraga spp.) [10] [11]. Slow-growing woody perennials such as Dryas integrifolia, Salix arctica, and Saxifraga oppositifolia are often undetectable or do not provide significant plant cover until much later in the natural succession process, if at all [11]-[13]. As species turnover is low in arctic and alpine ecosystems, early colonizing species may become part of the late successional stage. Regeneration of plant cover can be further inhibited by factors such as unviable seeds, herbivory, soil compaction, and substrate instability [5]-[7] [14]. Understanding expected successional pathways following disturbances can help accelerate revegetation by identifying factors limiting species establishment and growth [15].

Assisted revegetation is an active process in which seeds from native or non-native species are selectively sowed, and/or cuttings from slow-growing woody perennial shrubs are planted onto disturbed areas to accelerate the rate of plant coverage. Species selection following disturbance is based on revegetation goals and objectives. For ecological restoration, the goal is to develop self-supporting vegetation with similar structure, function and plant communities as found in the original environment [16]. In comparison, reclamation of disturbed land aims to control erosion, provide immediate forage for herbivores, improve aesthetics and/or prevent encroachment of invasive species using native or non-native species [11] [16] [17]. Various studies of assisted revegetation using seeds and tillers of grasses and other graminoid plants, legumes, and cuttings of Salix ssp. have been conducted in northern Alaska, Canada, Greenland, Iceland and north-west Siberia to quickly cover disturbed areas and to 


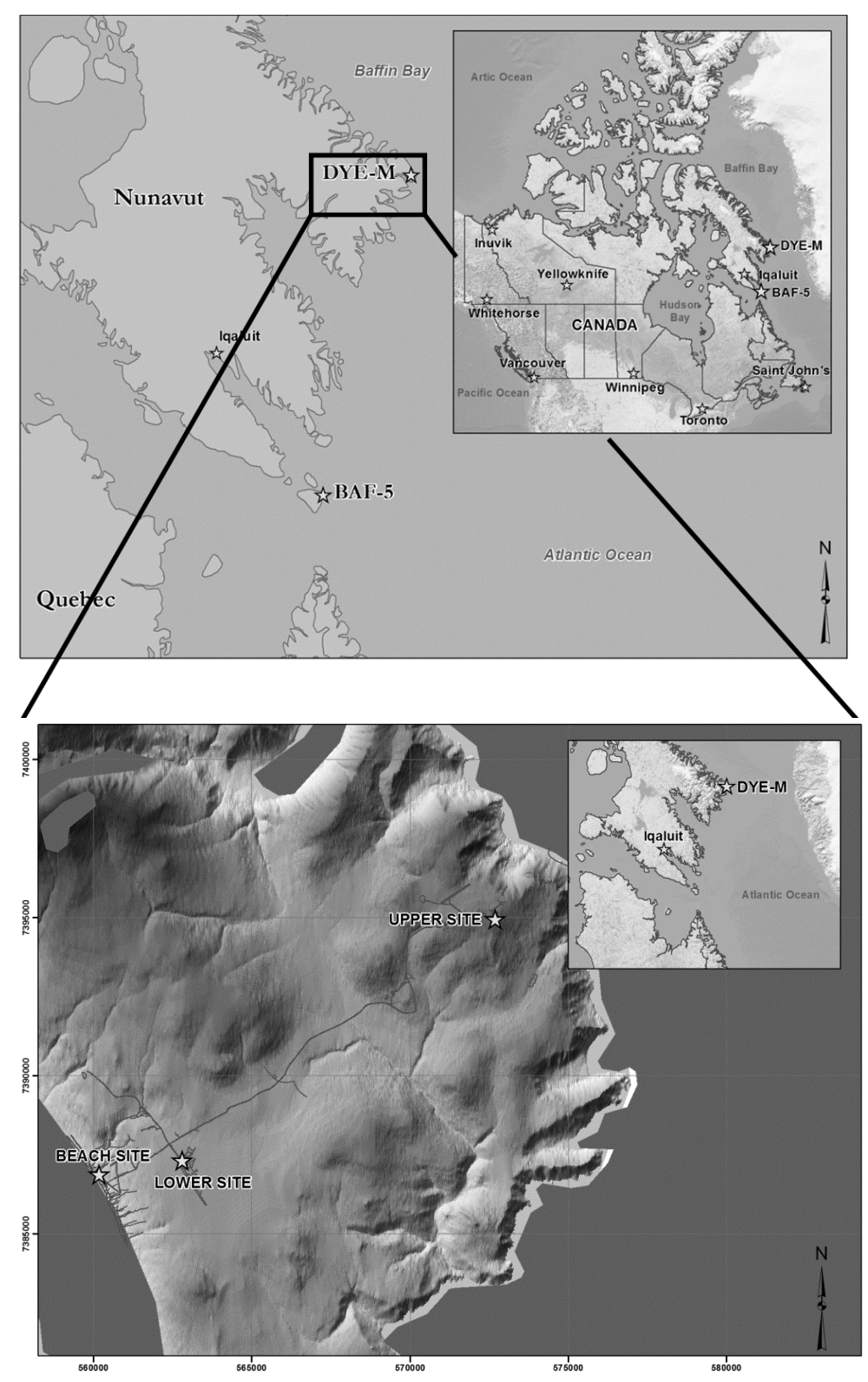

Figure 1. Location of DYE-M, Cape Dyer, Nunavut. Bottom figure shows the locations of the Upper (Radar station), Lower (Logistics and housing), and Beach (revegetation area) sites at DYE-M.

re-establish a plant community (reviewed in [6]). In particular, Lolium multiflorum (annual ryegrass) has been used as a "nurse grass" in previous remediation projects in Alaska and the Yukon to help prevent further erosion by establishing an immediate plant community, improve nutrient content in the top layer of the soil, create safe microenvironments to enhance germination, and provide windbreaks to help trap native seeds blowing across unvegetated areas of the site [8] [18] [19]. When possible, the use of native species is preferred as they are more adapted to the environment and will generally blend in better with the surrounding areas. However, as it can be difficult to obtain appropriate seeds or plant material in sufficient quantities to remediate large areas [6] [7] [17], reclamation and ecological restoration in the north following disturbance have not yet been achieved with much success.

A four-year revegetation project was undertaken at the DYE-M beach site between 2009 and 2012 to accelerate recovery of disturbed areas. The short-term objective was to investigate the feasibility of, and devise a plan 
to, accelerate revegetation of disturbed areas through assisted seed dispersal and selective transplantation of slow-growing shrub species. The long-term goal was to monitor successional changes towards achievement of comparable species biodiversity and vegetation coverage in the disturbed and surrounding areas at this arctic site.

\section{Materials and Methods}

\subsection{Ecoclimate Characteristics}

DYE-M has a high arctic ecoclimate with long cold winters with an average winter temperature of $-22.5^{\circ} \mathrm{C}$, an annual temperature of $-11.5^{\circ} \mathrm{C}$ and short, very cold summers with an average summer temperature of $1^{\circ} \mathrm{C}$ [20]. Annual precipitation is approximately $200-400 \mathrm{~mm}$ in the ecoregion, with deep continuous permafrost, bare rock and turbic cryosols. Vegetation has low diversity and sparse cover, with a mix of low-growing herbs, shrubs, heath species, mosses and lichens.

\subsection{Initial Site Assessments}

Plant surveys were completed in July 2009 at DYE-M to determine the density and biodiversity of different species growing in the undisturbed areas surrounding the disturbed area at the beach to define a baseline for the project and a long-term goal for revegetation. Six transects (40 - $100 \mathrm{~m}$ long) were established in undisturbed areas, and quadrats $\left(1-\mathrm{m}^{2}\right)$ were set up every $10 \mathrm{~m}$ along each transect $(\mathrm{n}=60)$ to determine the percent coverage of each plant species and the percent of bare soil/rocks. Plants were identified using Barrenland Beauties [21] and Vascular Plants of Continental Northwest Territories, Canada [22], and identifications were verified by an independent plant expert at Queen’s University (Supplementary Information Table 1).

Two soil samples were collected from the disturbed area $(0-10 \mathrm{~cm})$ and two from the undisturbed surrounding

Table 1. Plant species observed on the beach area of Cape Dyer, July 2009.

\begin{tabular}{|c|c|c|c|c|}
\hline Latin Name & Common Name & Root Structure & Shoot Structure & Reproductive Method \\
\hline $\begin{array}{l}\text { Armeriamaritimasubsp. sibirica } \\
\text { (Turcz. Ex Boiss.) Nyman }\end{array}$ & sea pink/thrift & taproot & evergreen perennial & seeds \\
\hline $\begin{array}{l}\text { Carex bigelowii } \\
\text { (Torr ex Schwein) }\end{array}$ & sedge & fibrous & $\begin{array}{l}\text { perennial } \\
\text { herb-graminoid }\end{array}$ & rhizomes/stolons/achenes \\
\hline Cassiopetetragona (L.) D. Don & $\begin{array}{l}\text { white Arctic heather/Arctic bell } \\
\text { heather }\end{array}$ & $\begin{array}{l}\text { fibrous roots along } \\
\text { stem }\end{array}$ & $\begin{array}{c}\text { dwarf } \\
\text { shrub-evergreen }\end{array}$ & seeds \\
\hline Cerastium uniflorum Clairv. & glacier mouse-ear chickweed & Fibrous & forb & seeds \\
\hline Chamerion latifolium (L.) Holub & $\begin{array}{l}\text { river beauty/dwarf fireweed/ } \\
\text { broad-leafed willow herb }\end{array}$ & fibrous & perennial herb-forb & rhizomes/seeds \\
\hline Dryas octopetala L. & mountain avens & $\begin{array}{l}\text { taproot/lateral roots } \\
\text { from stem }\end{array}$ & dwarf shrub & fruit, branches root \\
\hline Empetrum nigrum L. & crowberry & \multicolumn{2}{|c|}{ lateral roots from stem dwarf shrub evergreen } & seeds in fruit/branches root \\
\hline $\begin{array}{c}\text { Hierochloe alpine } \\
\text { (Sw. ex Willd.) } \\
\text { Roem. \& Schult. }\end{array}$ & holy grass & fibrous & graminoid & rhizomes, seeds \\
\hline Luzula confusa (Lindeberg) & northern woodrush & fibrous & $\begin{array}{c}\text { perennial } \\
\text { herb-graminoid }\end{array}$ & rhizomes/seeds \\
\hline Oxyria digyna (L.) Hill & mountain sorrel & taproot & perennial herb-forb & rhizomes/seeds \\
\hline Papaver radicatum $L$. & Arctic poppy & fibrous/taproot & perennial herb-forb & seeds \\
\hline Polygonum viviparum L. & alpine bistort & fibrous & perennial herb & $\begin{array}{l}\text { bulbils/fragmentation } \\
\text { rhizomes/achenes }\end{array}$ \\
\hline Salix arctica Pall. & Arctic willow & lateral roots from stem & dwarf shrub & seeds/branches root \\
\hline Silene acaulis L. Jacq. & moss campion & taproot & $\begin{array}{l}\text { perennial herb- } \\
\text { forb-cushion plant }\end{array}$ & rhizomes, seeds, stolons \\
\hline Vaccinium uliginosum L. & whortleberry/bilberry & roots along stem & dwarf shrub & seeds \\
\hline
\end{tabular}


area and analyzed for total organic carbon (TOC) and particle sizeto determine if there were differences in the soil composition that might affect revegetation.

\subsection{Revegetation Techniques}

\subsubsection{Site Preparation}

A loader tractor with a tooth bucket was used to create grooves across the disturbed area which had been heavily compacted by machinery. Grooves were created by dragging the bucket perpendicular to the direction of prevailing winds, creating ridges approximately $10-15 \mathrm{~cm}$ deep, and $20 \mathrm{~cm}$ apart. In 2009, it was suggested by an on-site remediation design engineer that a section of the disturbed area be amended with an Agrico Canada Ltd fertilizer (available in large quantities at the site for hydrocarbon remediation in landfarms) prior to seeding. As the disturbed areas overlooked Exeter Bay, the use of this fertilizer was deemed inappropriate for this project since the MSDS literature indicated potential harm to aquatic organisms.

\subsubsection{Salix arctica Transplantation Techniques}

Salix arctica Pall. (willow) cuttings were harvested from a donor population near the beach after a frost in September 2009. A shoot segment $30-150 \mathrm{~cm}$ long and $\sim 1-2 \mathrm{~cm}$ in diameter was cut from the stem of each donor willow plant with pruning shears, and kept in water until time of transplantation ( $<10 \mathrm{hrs}$ ). Longer cuttings ( $>40$ $\mathrm{cm}$ ) were further separated into two or more cuttings before transplantation as recommended by Walter et al. [23]. Cuttings were folded in three, and then buried in holes (10 - $15 \mathrm{~cm}$ deep) that were created on an angle with a pick-axe (R. Lewis 2009, personal conversation). Care was taken to ensure that one or two leaf buds were above the surface of the soil. A total of 540 willow cuttings were planted in 26 plots of 12, 16, 20 or 25 cuttings(based on space and amount of collected material) to create small "islands" within the unvegetated area to accelerate growth of these slow-growing woody perennial species. Four to five cuttings were planted in a row, with four to five rows per plot. Cuttings were planted approximately $50-100 \mathrm{~cm}$ apart within a row, and the next row was offset by approximately $50-100 \mathrm{~cm}$ so cuttings in two adjacent rows were not directly in line creating a diamond-shaped pattern as recommended by Walter et al. [23]. The use of islands was chosen as a revegetation strategy as the areal extent of the unvegetated areas was too large to economically cover completely with cuttings [24]. Plots were randomly distributed across the disturbed area with cuttings located on flat and sloped areas.

Another 150 cuttings were transplanted in the fall of 2011. Cuttings were again collected following a frost from donor plants located in areas surrounding the disturbed area. Five plots were planted with 27 - 30 willow cuttings using the same method as those planted in 2009, whereas a sixth plot was planted with a modified approach in which willows were planted in long trenches in a staggered pattern so plants could lie in their natural orientation and nodal root growth could be encouraged [23]. These longer and shallower trenches were at times easier to dig in the rocky ground than vertical holes (as buried boulders need to be moved or planting sites repeatedly shifted). In addition to burying three quarters of the plant cutting in soil to encourage root development, the existing secondary root structures along the exposed region of the cutting were covered with small mounds of soil to promote nodal root development.

\subsubsection{Seed Collection and Seeding Techniques}

Twenty-two kg of Lolium multiflorum (annual ryegrass; Lot L19-8-22G) obtained from Country Depot in Kingston Ontario, was seeded by hand across $\sim 7900 \mathrm{~m}^{2}$ of the disturbed area at a rate of $29 \mathrm{~kg} / \mathrm{ha}$ (commercial seeding rates $=15-30 \mathrm{~kg} / \mathrm{ha}$ ).

Ripe seeds and berries from native plants were collected by hand into five large ziplock bags (3.8 L each) from the areas above and below the disturbed area. Seeds were of different shapes, sizes, and weights based on their dispersal mechanisms. Each bag contained a different mix of seeds and berries based on the collection area; therefore seed density was not calculated prior to dispersal. Native seed was mixed by hand to create a more homogenous mix of seeds and berries and then dispersed by hand on the same area $\left(\sim 7900 \mathrm{~m}^{2}\right)$ as the annual ryegrass. Seeds were not tested for germination prior to dispersal. Future studies are required to investigate seed germination and seedling survival for seeds from this area. Following seed dispersal (native and non-native), seeds were covered with soil by attaching a large metal fence section ( 4 feet $\times 5$ feet) to the back of an all-terrain vehicle, and dragging it perpendicular to the direction of the ridges to help push loose soil into the grooves to cover the seeds. 


\subsection{Monitoring}

\subsubsection{Willow Cuttings}

Plantassessments were conducted in late July and early August in 2010, 2011, and 2012 to determine the number of Salix arctica cuttings that survived the winter and produced new shoot growth. New shoot growth was qualified as the observation of one or more leaves, and quantified in 2010 as, i) limited growth (1-2 leaves), ii) moderate growth (3 - 4 leaves) and iii) significant growth (4+ leaves). In 2011 and 2012, cuttings were determined to be alive (one or more leaves) or dead (no leaves). Four cuttings were excavated in 2010 to observe root growth from one plant with limited growth, one plant with moderate growth, and two plants with significant growth.

\subsubsection{Seedling Germination and Species Biodiversity}

Based on slow growth rates of Arctic plants, where most species are still relatively small during the first growing seasons [25], the use of $>20 \%$ frequency rather than $>2 \%$ ground cover or $>10 \mathrm{stems} / \mathrm{m}^{2}$ was chosen to measure initial success for the establishment of seedlings on the remediated areas at DYE-M in 2010, 2011 and 2012 [7] [26] [27]. Twenty-eight transects and $1361-\mathrm{m}^{2}$ quadrats were systematically established across the disturbed area in 2010to identify native plant species frequency and biodiversity. A more detailed assessment was conducted in 2011 using systematic transects and $3791-\mathrm{m}^{2}$ quadrats [28]. Due to time and weather constraints, only $151-\mathrm{m}^{2}$ quadrats were randomly established for monitoring in 2012. Loliummultiflorum was only assessed in 2010 as it is an annual species. Lolium multiflorum frequency and density were assessed in 2010 by counting individual plants in each quadrat.

\section{Results and Discussion}

\subsection{Initial Plant Survey Results}

Results from the initial survey of the surrounding area vegetation (i.e. prior to revegetation efforts) determined that on average, $\sim 68 \%$ of each quadrat at DYE-M was bare soil or rock, and the remaining $\sim 32 \%$ was a mixture of fifteen plant species (Figure 2). Plants identified at DYE-M were a mixture of woody perennial shrub-heath species, graminoids, and herbaceous perennial plants, though the three species with the most ground cover were Salix arctica ( 11\%), Vaccinium uliginosum L. ( 8\%), and Empetrum nigrum L. ( $\sim 5 \%)$, all of which are woody perennial species (Supplementary Information Table 1). In the arctic, the majority of plants tend to be perennial herbs, slow-growing woody-shrubs, or mosses and lichens, with very few annual species. Grasses and S. arctica were the most frequent species at DYE-M, appearing in 48 and 45 of the 60 quadrats, respectively (Figure 3). Visual surveys of the disturbed areas at DYE-M noted virtually no new plant growth.

Of the fifteen species observed on site in 2009, seven had fibrous root systems, four had taproot systems, and five were able to produce roots from prostrate shoot branches (Supplementary Information Table 1). Shoot structures of arctic plants tend to be low-lying forms that maximize plant exposure to sunlight, while minimizing the impact of low temperatures and strong winds. Low-lying plants are further protected during winter months by a snow cover that insulates them from extreme thermal and moisture conditions [29]. At DYE-M, plants generally had short and flexible shoot systems or were low-lying, woody perennials. Due to the short growing season, most species were flowering or nearing the end of their flowering period during the survey period in mid-July. In general, perennial species produce flower and leaf buds in the fall in preparation for the following season, before going dormant for the winter [5].

Soil analysis determined that the particle size ranged from $>0.001 \mathrm{~mm}$ to $>4 \mathrm{~mm}$; the majority of particles were $<4 \mathrm{~mm}$. Soil type was a mixture of sand (68\%), gravel (17\%), silt (11\%), and clay (4\%). Total organic carbon in the soil ranged from 0.22 to 0.91 for the reshaped areas, and from 0.68 to 0.86 for nearby samples from the undisturbed areas. These values are similar to carbon storage values reported for "c" horizons in various tundra environments, and for upper soil horizons in barren ground mountain tops, river gravel bar and alpine slope soil in Alaska [30].

Fertilizer has historically been scattered across disturbed areas during site closures in northern locations to decrease the amount of material that must be shipped back down south and to potentially improve revegetation of the disturbed areas. While fertilizer was not used in this project due to proximity to the aquatic environment, the use of fertilizers is often deemed necessary in arctic revegetation projects to promote plant growth, especially for non-native species, as the uppermost soil layer which generally contains nutrients and soil bacteria that 


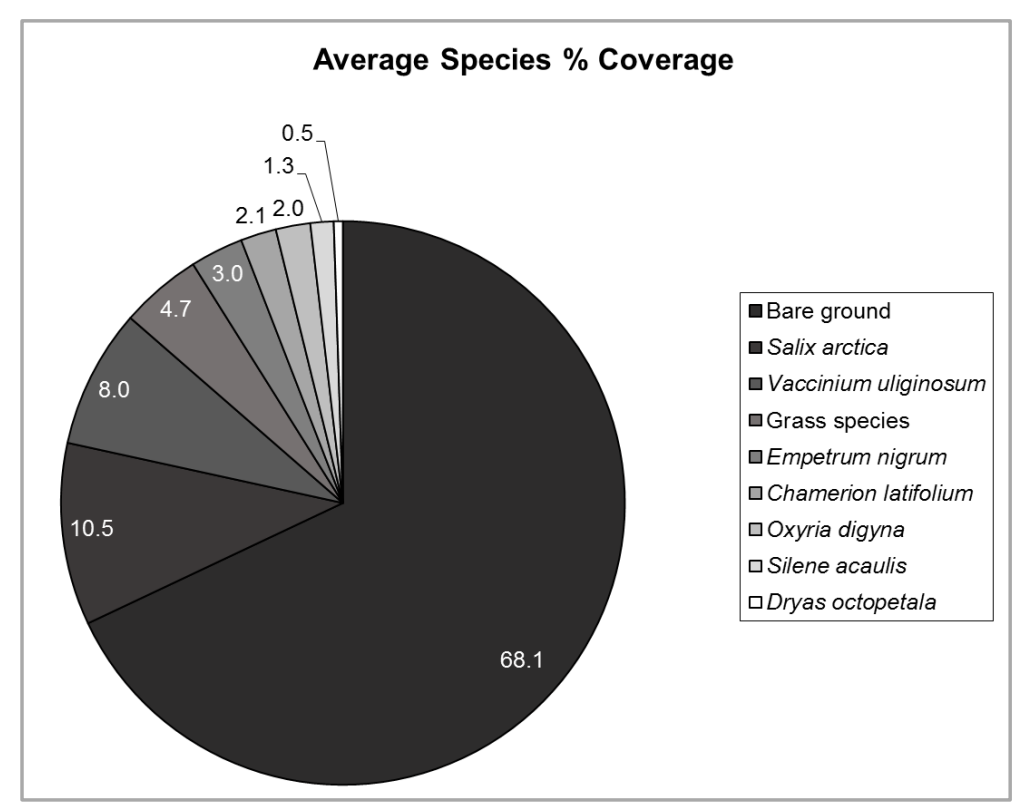

Figure 2. Mean percent coverage of the eight most common plant species across all quadrats.

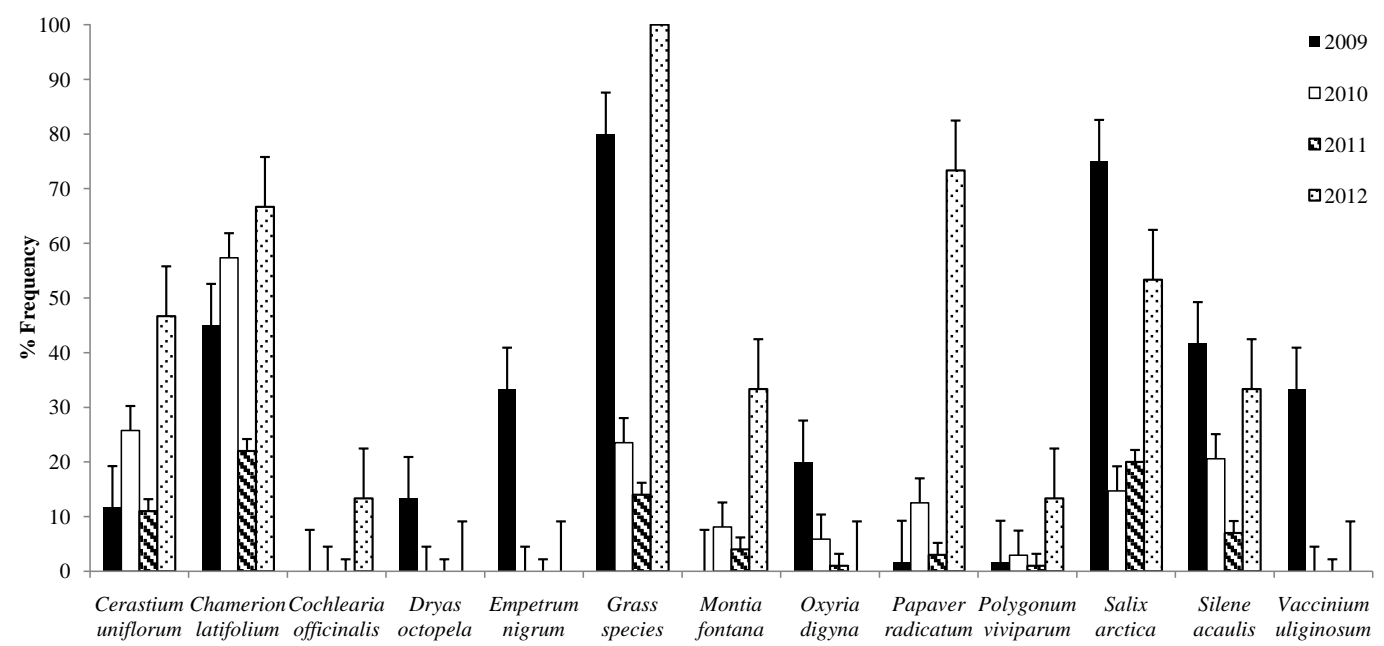

Figure 3. Frequency of species detected in quadrats between 2009 and 2012. Species identified in 2009 are from undisturbed locations. Species from 2010-2012 are from disturbed areas.

help cycle nutrients has generally been disturbed or removed by human activities [10] [17]. However, in some arctic environments, the use of fertilizers may be detrimental to some plants that are adapted to growing in nutrient-poor environments, or if non-native species become established due to a higher nutrient content, they may prevent re-colonization by native species through formation of a dense vegetation mat that is not easily penetrated [6] [13] [31]. For example, a study by Klokk and Rønning [10], determined that the effectiveness of fertilizer treatments on seven native species in Norway appeared to be species-specific. In future, controlled experiments conducted on a site-specific basis would be required to determine if fertilizer would benefit revegetation efforts at a specific site in the Arctic.

\subsubsection{Species Selection for Revegetation at DYE-M}

Prior to revegetation efforts at DYE-M, all fifteen species observed in the initial study were investigated to determine their revegetation potential based on: i) their ability to tolerate sandy soil, ii) their potential to improve 
the growth substrate, iii) whether they were perennials, iv) whether they were native to the Cape Dyer region, v) whether they could be obtained commercially or locally in sufficient quantities, vi) whether they had previously been shown to be successful in revegetation studies, and vii) whether they had the ability to prevent further erosion on the site (adapted from [7]). Of the fifteen identified species, all were perennial and capable of reproducing by seeds or achenes, and some could also reproduce by rhizomes, stolons and rooting from prostrate shoots (Supplementary Information Table 1). Based on recommendations by R. Lewis from Arctic Alpine Seed Ltd (personal conversation, 2009) and the criteria above, it was determined that seeds from all species observed at Cape Dyer would be collected from the surrounding areas for assisted seed dispersal as commercial sources of native arctic seeds were not available in sufficient quantities. In addition, Lolium multiflorum(annual ryegrass) was recommended as a nurse species to help prevent erosion and to improve the nutrient content in the soil.

\subsection{Revegetation Results 2010-2012}

\subsubsection{Survival Rate and Growth of Salix arctica Cuttings 2010-2012}

Ninety-four percent of the $540 \mathrm{~S}$. arctica cuttings planted in 2009 survived the winter and produced new shoot growth in 2010. First year survival rates greater than $80 \%$ are considered successful for Salix sp. cuttings [32], while Densmore et al. [33] reported survival rates between $86 \%$ - 96\% for different lengths of Salix alaxensis cuttings after one year of growth in Alaska. In this study, S. arctica cuttings continued to develop new shoot growth after initial observations in mid-July. Catkins were observed on some plants during the survey period.

Root growth assessments determined that roots ranged in length from non-existent (plant with limited shoot growth), to extensive (plant with significant shoot growth) with roots $>10 \mathrm{~cm}$ long and secondary and tertiary root development. Maximum root growth was observed in damp but not flooded areas. Visual observations of $S$. arctica from other areas around the site support the observation that plant growth is greatest in areas that offer refuge from strong winds (along rocks and boulders), as well as providing a significant source of soil water content (near water pools and along water run-off areas). Furthermore, these $S$. arctica tend to have well-developed secondary root growth along the full length of the stem (Figure 4).

In 2011, two landslides, one in June and one in late August, carrying rock and sediment debris from the road and hillside above the beach impacted six of the revegetation plots. Only thirty-five of the 88 willow cuttings from these plots survived. Initial observations from late July indicated that most cuttings in the other areas were producing leaves, but that secondary root development and shoot length growth was limited. This is to be expected as growth in the arctic is slow and significant change in size may take years of observation. Plant surveys were conducted six weeks later in September, and it was determined that some cuttings that had been judged unsuccessful in July had multiple leaves and appeared to be in significantly better health. Based on the September observations, 84\% of the 428 S. arctica cuttings found in 2011 had survived since 2009. Results from 2010 and 2011 indicate that end-of-season observations provide a more realistic indication of overall plant health and survivorship than early or mid-season observations.

Plant surveys were conducted in August 2012, following another landslide in July which impacted a similar area as in 2011. Another two plots were compromised by this third landslide, leaving only 29 of the 128 willows in this area. In addition, road work destroyed another two plots (24 cuttings). Of the remaining 388 cuttings not impacted by landslides or other disturbances, $82 \%$ survived to year three. This three year survival rate of $82 \%$ is similar to observations from a revegetation effort following an oil spill along the Trans-Alaska pipeline in 2001, where $80 \%-88 \%$ of transplanted willow cuttings survived after three years [34]. Observations of surviving plants at DYE-M indicated that many plants were starting to produce new stem tissue as well as new leaves, with many plants having 50+ leaves by the start of August, 2012. However, Densmore et al. [33] reported that long-term survival dropped to $53 \%$ after nine years, indicating that long-term monitoring and further transplantation of cuttings may be necessary to ensure long-term revegetation success. Of the 178 new cuttings planted in 2011, 93\% survived the first winter and were producing leaves in 2012, indicating similar one year success as the first set of cuttings. The sixth plot planted with the alternative method had the lowest survival rate (89\%), but the surviving plants had the most leaves along the aboveground shoot tissue. Encouragement of nodal adventitious roots has been shown to significantly increase stem length in Cucurbita pepo L. [35]. Methods to optimize root development and formation along stem tissues require further investigation in shrub species.

\subsubsection{Lolium multiflorum (Annual Ryegrass) Results}

Lolium multiflorum (annual ryegrass) seeded at a planted density of $29 \mathrm{~kg} / \mathrm{ha}$ in 2009 , was observed in $85 \%$ of 


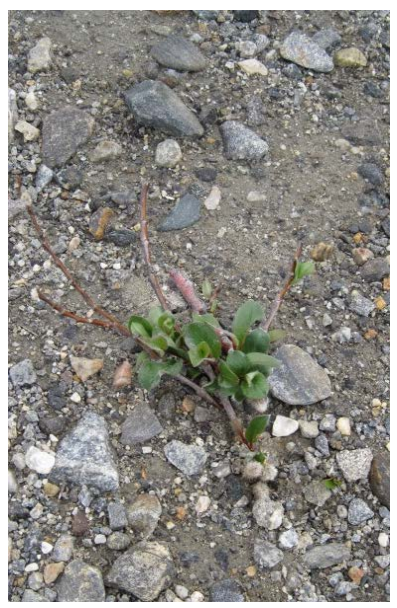

(a)

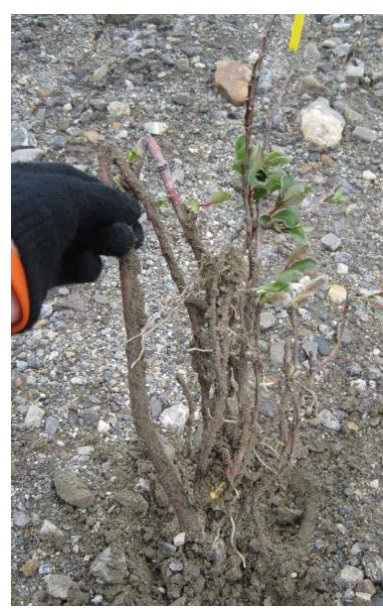

(b)

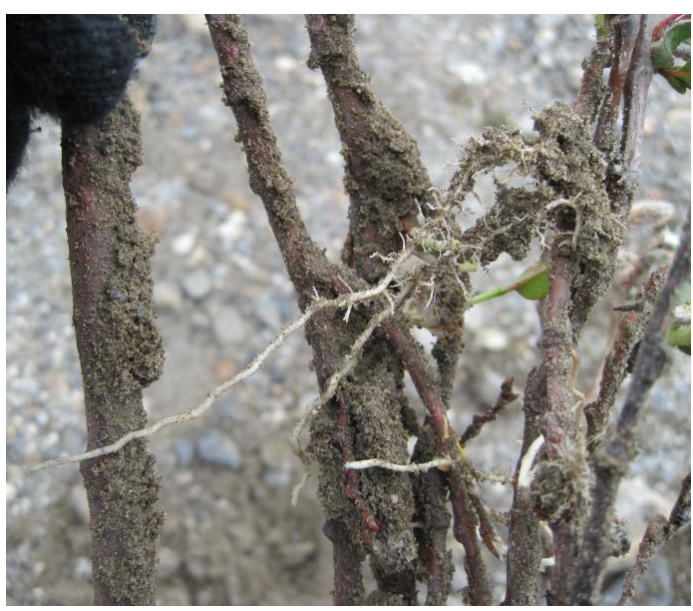

(c)

Figure 4. (a) One-year-old Salix arctica cutting with significant shoot growth; (b) Root system developing along underground portions of the transplanted stem cutting; (c) Close-up of root development $(\sim 10 \mathrm{~cm})$.

all quadrats, with a maximum density of 198 plants $/ 100 \mathrm{~cm}^{2}$. While the majority of L. multiflorum germinated and grew in 2010, a minority of seeds germinated in 2011 and 2012. No plants had developed spikes or inflorescences by the end of July, 2010, and all plants appeared so be stunted by the cold climate, with heights between $5-10 \mathrm{~cm}$, in comparison to normal heights up to $125 \mathrm{~cm}$ [36]. The majority of plants were observed in furrows or around the edges of boulders where they were slightly protected from the wind. Dead shoot tissue from plants that grew in 2010 was no longer present in 2012. This material is expected to help introduce organic material into the top layer of soil. Thus while seeding densities of $L$. multiflorum between 3.5 to $30 \mathrm{~kg} / \mathrm{ha}$ have been used in previous studies [8] [37] [38], a higher planting density may be necessary in extremely exposed Arctic environments when used for erosion prevention and/or as nurse grass for native species to ensure growth of a sufficient quantity of shoot material. However, care must be taken to ensure that the selected species is not seeded too densely or it might prevent germination and growth of native species, particularly if it is a perennial species [16] [39].

\subsubsection{Native Species Seeding Results}

Previous studies have used various guidelines to determine the success of revegetation projects, including colonization by native plants and establishment of seedlings, increased species diversity, reproduction by colonizing species, development of a moss layer, accumulation of ground litter, and 85\% total plant cover [40]-[43]. Quantitative criteria used by Kershaw and Kershaw [27], and Rausch and Kershaw [7] to evaluate successful colonizers of long-term natural revegetation projects under extreme growth conditions included species that met at least one of, $>2 \%$ ground cover, $>20 \%$ frequency, or $>10$ stems $/ \mathrm{m}^{2}$. Seedlings and plants from 14 species were observed in the quadrats or along transects between 2010 and 2012, in comparison to the 15 species recorded from plant surveys of the surrounding areas in 2009. Ground cover was not determined on an individual or total species basis during the surveys due to the low species diversity per plot and small size of plants. Of the 14 species observed during these three years, Chamerion latifolium (L.) Holub was the only species to have greater than $20 \%$ frequency every year, including in 2009 (22\% - 67\%), (Figure 3). Other species with greater than 20\% frequency during at least one year of monitoring included Cerastium uniflorum Clairv. (11\% - 47\%), mixed grasses (14\% - 100\%), Montia fontana L. (0\% - 33\%), Papaver radicatum Rottb. (2\% - 73\%), S. arctica (15\% - 75\%), and Silene acaulis (L.) Jacq. (7\% - 42\%) (Figure 3).

New species observed on the disturbed areas included Cochlearia officinalis L., Melandrium affine (J. Vahl ex Fr.) J. Vahl, and M. fontana [21], while slow-growing heath-shrub species Cassiope tetragona (L.) D. Don, Dryas octopetala L., Empetrum nigrum, and Vaccinium uliginosum were not recorded on the remediated areas. In temperate locations, plant communities develop over time through a series of natural succession events, whereby initial colonizing species are gradually replaced by other species, often with slower dispersion techniques [44]. All 14 species observed in the remediated areas have wind or bird-dispersed seeds or produce bulbils, helping them to colonize disturbed areas in the first phase of plant succession. In natural environments fol- 
lowing disturbance such as fire, the soil seed bank can accelerate site recovery, as seed banks generally represent the established vegetation in the area with the exception of woody perennial species [45]. However, this area has a history of repetitive disturbances, and the minimal topsoil that may have been present on the disturbed areas was not salvaged prior to landfill excavation. In future, preservation of this top layer of soil could introduce seeds and organic matter which can accelerate development of a natural plant community and provide the most widespread initial coverage, leading to long-term soil stability. This is particularly important in the Eastern Arctic, where no commercial seed mixture is currently available.

Despite the harsh climate and unpredictable weather patterns in the arctic that make revegetation work difficult, visual observations of the disturbed areas in 2012 indicated that patches of new vegetation are becoming more predominant compared to the almost complete lack of vegetation in 2009. Arctic plant communities are slow growing and seedling distribution tends to be skewed towards those sites that offer favourable conditions and are in close proximity to native tundra. Germination sites or microsites may be created naturally such as by desiccation cracks in the ground [46], or may be created with assistance. For example, Cater et al. [37] used a track vehicle to scarify the ground prior to seeding. These microsites are important for trapping seeds during dispersal, and also create a microclimate with specific properties favoured by plants including a greater mean soil temperature, lower wind speed, increased soil moisture and superior soil nitrate levels [46]. In this study, most seedlings were initially observed growing within furrows or around windbreaks such as the edges of rocks, as seeds were less likely to be blown or washed away, and/or sheltered within depressions, which provide suitable microclimates for germination and growth. However, the furrows created in 2009 had almost completely been smoothed over by 2012. A higher density of new seedlings was also observed around S. arctica patches, indicating that S. arctica "islands" are likely trapping seeds blowing across the unvegetated areas, and providing safe sites and microclimates that enhance seed germination and seedling growth. In addition, shrub species such as S. arctica may protect and insulate herbaceous species during the winter from extreme temperatures and winds by trapping snow in the branches, which promotes plant establishment [47]. Thus initial observations indicate that loosening soil prior to seeding and creating S. arctica islands enhances revegetation and may increase the probability of long term success.

\section{Conclusion}

As seedling growth is a slow process, monitoring over ten or more years will likely be required before conclusively declaring the disturbed areas partially or wholly revegetated. The information and techniques developed for this project can be used to guide the long-term remediation and revegetation strategies at other DEW line and high arctic sites following large scale disturbances. Future studies could incorporate assessment of native seed germination and survival rates, germination rates from the seedbank, permanent monitoring plots and use of other shrub species to improve diversity and long term monitoring of disturbed sites.

\section{Acknowledgements}

The authors are indebted to members of the Environmental Sciences Group (ESG) who have been involved in the DYE-M Clean up project over the years. We are grateful for the help provided in the field, and for the funding provided by North Warning System Office (NWSO) for this project.

\section{References}

[1] Royal Roads Military College Environmental Science Group (RRMC ESG) (1991) North Warning System Environmental Study, v. 1 Overview. Royal Roads Military College, Victoria.

[2] Stow, J.P., Sova, J. and Reimer, K.J. (2005) The Relative Influence of Distant and Local (DEW-Line) PCB Sources in the Canadian Arctic. Science of the Total Environment, 342, 107-118. http://dx.doi.org/10.1016/j.scitotenv.2004.12.028

[3] Environmental Sciences Group (2002) DYE-MAIN Cape Dyer, Nunavut Upper Site Investigation, 1997-2001. RMCCCE-ES-02-16. Environmental Sciences Group, Kingston.

[4] Environmental Sciences Group (2013) DYE-MAIN Cape Dyer, Nunavut Lower Site Investigation, 1997-2001. RMCCCE-ES-13-14. Environmental Sciences Group, Kingston.

[5] Billings, W.D. (1987) Constraints to Plant Growth, Reproduction, and Establishment in Arctic Environments. Arctic and Alpine Research, 19, 357-365. http://dx.doi.org/10.2307/1551400 
[6] Forbes, B.C. and Jefferies, R.L. (1999) Revegetation of Disturbed Arctic Sites: Constraints and Applications. Biological Conservation, 88, 15-24. http://dx.doi.org/10.1016/S0006-3207(98)00095-0

[7] Rausch, J. and Kershaw, G.P. (2007) Short-Term Revegetation Performance on Gravel-Dominated, Human-Induced Disturbances, Churchill, Manitoba, Canada. Arctic, Antarctic, and Alpine Research, 39, 16-24. http://dx.doi.org/10.1657/1523-0430(2007)39[16:SRPOGH]2.0.CO;2

[8] Densmore, R.V., Vander Meer, M.E. and Dunkle, N.G. (2000) Native Plant Revegetation Manual for Denali National Park and Preserve. Information and Technology Report USGS/BRD/ITR-2000-0006. Alaska Science Center, Biological Resources Division, Anchorage.

[9] Harper, K.A. and Kershaw, G.P. (1996) Natural Revegetation on Borrow Pits and Vehicle Tracks in Shrub Tundra, 48 Years Following Construction of the CANOL No. 1 Pipeline, N.W.T., Canada. Arctic and Alpine Research, 28, 163171. http://dx.doi.org/10.2307/1551756

[10] Klokk, T. and Rønning, O.I. (1987) Revegetation Experiments at Ny-Ålesund, Spitsbergen, Svalbard. Arctic and Alpine Research, 19, 549-553. http://dx.doi.org/10.2307/1551424

[11] Babb, T.A. and Bliss, L.C. (1974) Effects of Physical Disturbance on Arctic Vegetation in the Queen Elizabeth Islands. Journal of Applied Ecology, 11, 549-562. http://dx.doi.org/10.2307/2402208

[12] Evju, M., Hagen, D. and Hofgaard, A. (2012) Effects of Disturbance on Plant Regrowth along Snow Pack Gradients in Alpine Habitats. Plant Ecology, 213, 1345-1355. http://dx.doi.org/10.1007/s11258-012-0094-5

[13] Hagen, D. and Evju, M. (2013) Using Short-Term Monitoring Data to Achieve Goals in a Large-Scale Restoration. Ecology and Society, 18, 29. http://dx.doi.org/10.5751/ES-05769-180329

[14] Deshaies, A., Boudreau, S. and Harper, K. (2009) Assisted Revegetation in a Subarctic Environment: Effects of Fertilization on the Performance of Three Indigenous Plant Species. Arctic, Antarctic, and Alpine Research, 41, 434-441. http://dx.doi.org/10.1657/1938-4246-41.4.434

[15] Polster, D. (1991) Natural Vegetation Succession and Sustainable Reclamation. The Technical and Research Committee on Reclamation. Proceedings of the 15th Annual British Columbia Mine Reclamation Symposium, Kamloops, 5969.

[16] Matheus, P. and Omtzigt, T. (2012) Yukon Revegetation Manual: Practical Approaches and Methods. 176 p. http://www.yukoncollege.yk.ca/downloads/Yukon\%20-Revegetation-Manual.pdf.

[17] Wright, S.J. (2008) A Revegetation Manual for Alaska. Alaska Plant Materials Center, Palmer.

[18] Elmarsdottir, A., Aradottir, A. and Trlica, M.J. (2003) Microsite Availability and Establishment of Native Species on Degraded and Reclaimed Sites. Journal of Applied Ecology, 40, 815-823. http://dx.doi.org/10.1046/j.1365-2664.2003.00848.x

[19] Jupponen, A., Väre, H., Mattson, K.G., Ohtonen, R. and Trappe, J.M. (1999) Characterization of 'Safe Sites' for Pioneers in Primary Succession on Recently Deglaciated Terrain. Journal of Ecology, 87, 98-105. http://dx.doi.org/10.1046/j.1365-2745.1999.00328.x

[20] Ecological Stratification Working Group (1995) A National Ecological Framework for Canada. Agriculture and AgriFood Canada, Research Branch, Centre for Land and Biological Resources Research and Environment Canada, State of the Environment Directorate, Ecozone Analysis Branch, Ottawa/Hull. Report and National Map at 1:7500,000 Scale.

[21] Burt, P. (2000) Barrenland Beauties: Showy Plants of the Canadian Arctic. The Northern Publisher, Yellowknife.

[22] Porsild, A.E. and Cody, W.J. (1980) Vascular Plants of Continental Northwest Territories, Canada. National Museum of National Sciences, Ottawa. http://dx.doi.org/10.5962/bhl.title.70336

[23] Walter, J., Hughes, D. and Moore, N.J. (2005) Streambank Revegetation and Protection: A Guide for Alaska. Original Technical Report No. 98-3, Alaska Department of Fish and Game, Division of Sport Fish, Juneau, Alaska. http://www.adfg.alaska.gov/index.cfm?adfg=streambankprotection.main.

[24] Bittman, K.K. (1997) High Elevation Native Species Island Model for Mine Reclamation, Quintette Operating Corporation. The Technical and Research Committee on Reclamation. Proceedings of the 21st Annual British Columbia Mine Reclamation Symposium, Cranbrook, 22-25 September 1997.

[25] Billings, W.D. and Mooney, H.A. (1968) The Ecology of Arctic and Alpine Plants. Biological Reviews, 43, $481-529$. http://dx.doi.org/10.1111/j.1469-185X.1968.tb00968.x

[26] Ficko, S. and Zeeb, B. (2009) The DYE-M Beach Site Revegetation Project Report 2009. Environmental Sciences Group, Royal Military College of Canada, Kingston.

[27] Kershaw, G.P. and Kershaw, L.J. (1987) Successful Plant Colonizers on Disturbances in Tundra Areas of Northwestern Canada. Arctic and Alpine Research, 19, 451-460. http://dx.doi.org/10.2307/1551411

[28] Smith, B. and Zeeb, B. (2011) The DYE-M Beach Sites Revegetation Project Report 2011. Environmental Sciences Group, Royal Military College of Canada, Kingston. 
[29] Oksanen, L. (1990) Predation, Herbivory, and Plant Strategies along Gradients of Primary Productivity. In: Grace, J.B. and Tilman, D., Eds., Perspectives on Plant Competition, Academic Press, Inc., San Diego, 445-448. http://dx.doi.org/10.1016/b978-0-12-294452-9.50024-2

[30] Michaelson, G.J., Ping, C.L. and Kimble, J.M. (1996) Carbon Storage and Distribution in Tundra Soils of Arctic Alaska, U.S.A. Arctic and Alpine Research, 28, 414-424. http://dx.doi.org/10.2307/1551852

[31] Cargill Bishop, S. and Chapin, F.S. (1989) Patterns of Natural Revegetation on Abandoned Gravel Pads in Arctic Alaska. Journal of Applied Ecology, 26, 1073-1081. http://dx.doi.org/10.2307/2403713

[32] Bergkvist, P., Nordh, N., Ledin, S. and Olsson, T. (1996) Plant Material for Short Rotation Forestry. In: Ledin, S. and Willebrand, E., Eds., Handbook on How to Grow Short Rotation Forests, Swedish University of Agricultural Sciences, Department of Short Rotation Forestry, Uppsala, 11.6.1-11.6.20.

[33] Densmore, R.V., Neiland, B.J., Zasada, J.C. and Masters, M.A. (1987) Planting Willow for Moose Habitat Restoration on the North Slope of Alaska, USA. Arctic and Alpine Research, 19, 537-543. http://dx.doi.org/10.2307/1551422

[34] McKendrick, J.D. (2005) Final Monitoring Inspection Report Mile Post 400 Revegetation Site. Alyeska Pipeline Service Company, Fairbanks.

[35] Low, J., Whitfield Åslund, M., Rutter, A. and Zeeb, B.A. (2011) The Effects of Pruning and Nodal Adventitious Roots on Polychlorinated Biphenyl Uptake by Cucurbitapepo Grown in Field Conditions. Environmental Pollution, 159, 769-775. http://dx.doi.org/10.1016/j.envpol.2010.11.015

[36] Carey, J.H. (1995) Lolium multiflorum. In: Fire Effects Information System, U.S. Department of Agriculture, Forest Service, Rocky Mountain Research Station, Fire Sciences Laboratory. http://www.fs.fed.us/database/feis/

[37] Cater, T.C., Jorgenson, M.T., Bishop, S.C. and Rea, C.L. (2007) Erosion Control and Restoration of a Sand Dune on the Colville River Delta, Northern Alaska. Ecological Restoration, 24, 238-246. http://dx.doi.org/10.3368/er.25.4.238

[38] Vogel, W.G. (1987) A Manual for Training Reclamation Inspectors in the Fundamentals of Soils and Revegetation. U.S. Department of Agriculture, Northeastern Forest Experiment Station, Borea.

[39] Densmore, R.V. (1992) Succession on an Alaskan Tundra Disturbance with and without Assisted Revegetation with Grass. Arctic and Alpine Research, 24, 238-243. http://dx.doi.org/10.2307/1551663

[40] Gillis, A. (1991) Bringing Back the Land. Bioscience, 41, 68-71. http://dx.doi.org/10.2307/1311557

[41] McKendrick, J.D. (1997) 25 Years in Perspective: Arctic Tundra Revegetation. Agroborealis, 23, 29-40.

[42] Munshower, F. (2000) Reclamation of Gold Heaps and Metal Mine Wastes. In: Barnhisel, R.I., Darmody, R.G. and Daniels, W.L., Eds., The Reclamation of Drastically Disturbed Lands (Agronomy Monograph 41), American Society of Agronomy-Crop Science Society of America-Soil Science Society of America, Madison, 709-723.

[43] Streever, W.J., McKendrick, J., Fanter, L., Anderson, S.C., Kidd, J. and Portier, K.M. (2003) Evaluation of Percent Cover Requirements for Revegetation of Disturbed Sites on Alaska's North Slope. Arctic Institute of North America, 56, 234-248. http://dx.doi.org/10.14430/arctic619

[44] Walker, L.R. and del Moral, R. (2003) Primary Succession and Ecosystem Rehabilitation. Cambridge University Press, New York. http://dx.doi.org/10.1017/CBO9780511615078

[45] Cooper, E.J., Alsos, I.G., Hagen, D., Smith, F.M., Coulson, S.J. and Hodkinson, I.D. (2004) Plant Recruitment in the High Arctic: Seed Bank and Seedling Emergence on Svalbard. Journal of Vegetation Science, 15, 115-224. http://dx.doi.org/10.1111/j.1654-1103.2004.tb02244.x

[46] Sohlberg, H. and Bliss, L.C. (1984) Microscale Pattern of Vascular Plant Distribution in Two High Arctic Plant Communities. Canadian Journal of Botany, 62, 2033-2042. http://dx.doi.org/10.1139/b84-277

[47] Dona, A.J. and Galen, C. (2007) Nurse Effects of Alpine Willows (Salix) Enhance Over-Winter Survival at the Upper Range Limit of Fireweed, Chamerion augustifolium. Arctic, Antarctic and Alpine Research, 39, 57-64. http://dx.doi.org/10.1657/1523-0430(2007)39[57:NEOAWS]2.0.CO;2 